\title{
Halalkalibacillus halophilus gen. nov., sp. nov., a novel moderately halophilic and alkaliphilic bacterium isolated from a non-saline soil sample in Japan
}

Correspondence
Akinobu Echigo
dc0400017@toyonet.toyo.ac.jp

\author{
Akinobu Echigo, ${ }^{1,2}$ Tadamasa Fukushima, ${ }^{1,2}$ Toru Mizuki, ${ }^{1,2}$ \\ Masahiro Kamekura ${ }^{3}$ and Ron Usami ${ }^{1,2}$ \\ ${ }^{1}$ Department of Applied Chemistry, Faculty of Engineering, Toyo University, 2100 Kujirai, \\ Kawagoe, Saitama 350-8585, Japan \\ ${ }^{2}$ Bio-Nano Electronics Research Centre, Toyo University, 2100 Kujirai, Kawagoe, \\ Saitama 350-8585, Japan \\ ${ }^{3}$ Noda Institute for Scientific Research, 399 Noda, Noda, Chiba 278-0037, Japan
}

\begin{abstract}
A moderately halophilic and alkaliphilic bacterium, designated strain $\mathrm{BH}^{\top}{ }^{\top}$, was isolated from non-saline garden soil in Saitama, Japan. Cells of strain $\mathrm{BH} 2^{\top}$ were motile, aerobic, rod-shaped and Gram-positive and contained A1 $\gamma$, meso-diaminopimelic acid-type murein. Growth occurred in $5.0-25 \%(w / v) ~ N a C l$ (optimum, 10-15\%, w/v), at $\mathrm{pH} 5.5-10.0$ (optimum, $\mathrm{pH}$ 8.5-9.0) and at $20-40^{\circ} \mathrm{C}$. The predominant isoprenoid quinone was menaquinone-7. The major cellular fatty acids were ai- $\mathrm{C}_{15: 0}, \mathrm{i}-\mathrm{C}_{16: 0}$, ai- $\mathrm{C}_{17: 0}$ and $\mathrm{i}-\mathrm{C}_{15: 0}$. The $\mathrm{G}+\mathrm{C}$ content of the total DNA of strain $\mathrm{BH} 2^{\top}$ was $35.1 \pm 0.4 \mathrm{~mol} \%( \pm \mathrm{SD} ; n=5)$. The phylogenetic distance from species with validly published names was less than $94.1 \%$. The phylogenetic and phenotypic characteristics indicated that strain $\mathrm{BH} 2^{\top}$ represents a novel genus and species, for which the name Halalkalibacillus halophilus gen. nov., sp. nov. is proposed. The type strain is $\mathrm{BH}^{\top}\left(=\mathrm{JCM} 14192^{\top}=\mathrm{DSM} 18494^{\top}\right)$.
\end{abstract}

Halophilic micro-organisms are adapted to conditions of high salinity and require a certain concentration of $\mathrm{NaCl}$ for optimum growth (Kushner \& Kamekura, 1988; Oren, 2002). Moderate halophiles are defined as those that grow optimally in media containing 3-15\% (w/v) $\mathrm{NaCl}$. They have been isolated from various saline environments such as salt lakes (e.g. the Dead Sea and the Great Salt Lake), salterns, solar salts and subsurface salt formation. It is tacitly believed that the habitats of moderate halophiles are restricted to saline environments and no reports have been published on the isolation of moderately halophilic microorganisms from non-saline environments. In this study, we propose that a moderately halophilic and alkaliphilic bacterium isolated from a sample from ordinary non-saline garden soil represents a novel genus and species, based on phylogenetic and phenotypic characteristics.

\footnotetext{
Abbreviation: $m$-Dpm, meso-diaminopimelic acid.

The GenBank/EMBL/DDBJ accession number for the 16S rRNA gene sequence of strain $B 2^{\top}$ is $A B 264529$.

An alignment of $16 \mathrm{~S}$ rRNA gene sequences of members of the family Bacillaceae and a phylogenetic tree reconstructed from the alignment and signature bases of the genera Alkalibacillus, Filobacillus, Tenuibacillus and strain $\mathrm{BH} 2^{\top}$ are available as supplementary material in IJSEM Online.
}

Soil samples were taken from non-saline, ordinary gardens in many cities of Saitama Prefecture, Japan. Most of the gardens were full of trees and flowers. No highly saline environments such as salterns or salt lakes occur in the region. $\mathrm{NaCl}$ contents calculated by determining the $\mathrm{Cl}^{-}$ content of a soil extract with water using the method of Mohr (Lenore et al., 1998) were less than $0.1 \%(\mathrm{w} / \mathrm{v})$. The $\mathrm{pH}$ values of the soil extracts were slightly acidic, $\mathrm{pH}$ 5.0-6.0.

About $0.5 \mathrm{~g}$ of the soil sample was placed on an alkaline agar plate, spread with a spatula and incubated at $37^{\circ} \mathrm{C}$ for 3 weeks in a plastic bag to prevent desiccation. The medium used contained the following $\left(1^{-1}\right): 5.0 \mathrm{~g}$ Casamino acids (Difco), $5.0 \mathrm{~g}$ yeast extract (Difco), $1.0 \mathrm{~g}$ sodium glutamate. $\mathrm{H}_{2} \mathrm{O}, 3.0 \mathrm{~g}$ trisodium citrate. $2 \mathrm{H}_{2} \mathrm{O}, 2.0 \mathrm{~g} \mathrm{KCl}, 0.2 \mathrm{~g}$ $\mathrm{MgSO}_{4} .7 \mathrm{H}_{2} \mathrm{O}, 36 \mathrm{mg} \mathrm{FeCl} 2.4 \mathrm{H}_{2} \mathrm{O}, 200.0 \mathrm{~g}(3.4 \mathrm{M}) \mathrm{NaCl}$ and $20 \mathrm{~g}$ Bacto agar (Difco), pH 7.2. After autoclaving, the $\mathrm{pH}$ was adjusted to 9.5 by addition of pre-calculated amounts of sterile $\mathrm{Na}_{2} \mathrm{CO}_{3}$ solutions. Colonies were picked, transferred to fresh agar plates, and pure cultures were obtained by plating serial dilutions and repeated transfers on agar plates. Strain $\mathrm{BH} 2^{\mathrm{T}}$, isolated from non-saline surface soil from a garden in Niiza City, was selected for further characterization after sequencing of PCR-amplified 16S rRNA genes of a few isolates. 
Strain $\mathrm{BH} 2^{\mathrm{T}}$ grew in $5.0-25 \%(\mathrm{w} / \mathrm{v}) \mathrm{NaCl}\left(\mathrm{pH} 9.5,37^{\circ} \mathrm{C}\right)$, with optimum growth at $10-15 \%(\mathrm{w} / \mathrm{v}) \mathrm{NaCl}$. Growth occurred within the $\mathrm{pH}$ range $5.5-10.0[10 \%(\mathrm{w} / \mathrm{v}) \mathrm{NaCl}$, $37^{\circ} \mathrm{C}$, with optimum growth at $\mathrm{pH}$ 8.5-9.0. The temperature range for growth was $20-40{ }^{\circ} \mathrm{C}[10 \%(\mathrm{w} / \mathrm{v}) \mathrm{NaCl}$, $\mathrm{pH}$ 9.5], with optimum growth at $30-37^{\circ} \mathrm{C}$. Anaerobic growth was not observed using an anaerobic jar (Echigo et al., 2005) after incubation for 7 days at $37^{\circ} \mathrm{C}$.

Colonies of strain $\mathrm{BH}_{2}{ }^{\mathrm{T}}$ formed on agar $(10 \% \mathrm{NaCl}$, $\mathrm{pH} 9.5,37^{\circ} \mathrm{C}$ ) were cream-like and opaque. The cells were rod-shaped and approximately $0.3-0.5 \times 2.0-3.0 \mu \mathrm{m}$. The cells were motile with a single polar flagellum, observed according to Kodaka et al. (1982). Endospore formation was examined after spore-staining, according to the method of Wirtz-Conklin (Murray et al., 1999). A spherical terminal endospore with a swollen sporangium was produced (at $10 \% \mathrm{NaCl}, \mathrm{pH} 9.5,37^{\circ} \mathrm{C}$ ). Cells stained Gram-positive after acetic acid fixation, as described by Dussault (1955). The KOH test (Gregersen, 1978) and L-alanine aminopeptidase using Bactident Aminopeptidase test strips (Merck) were negative, as reported previously for Gram-positive bacteria (Gregersen, 1978).

Production of acid from carbohydrates was tested using media in which the amounts of Casamino acids and yeast extract were reduced to $1.0 \mathrm{~g} \mathrm{l}^{-1}$, supplemented with $10.0 \mathrm{~g} \mathrm{l}^{-1}$ of the test carbohydrate. The cultures were incubated at $37^{\circ} \mathrm{C}$ under aerobic conditions for 3 days. Growth was determined visually and the $\mathrm{pH}$ was measured with a $\mathrm{pH}$ electrode. Strain $\mathrm{BH}^{\mathrm{T}}$ did not produce acid from D-galactose, maltose, sucrose, D-trehalose, D-mannitol, D-fructose, D-glucose or D-xylose. Tests for catalase and oxidase activities and hydrolysis of starch, gelatin, casein, DNA, hippurate, aesculin, pullulan and Tween 80 were performed according to the standard or modified procedures of Smibert \& Krieg (1994), Oren et al. (1997) and Schlesner et al. (2001). Strain $\mathrm{BH}^{\mathrm{T}}$ was catalase- and oxidase-positive and did not hydrolyse starch, casein, gelatin, DNA, hippurate, aesculin, pullulan or Tween 80 . Reduction of nitrate was not detected using the sulfanilic acid and $\alpha$-naphthylamine reagent (Smibert \& Krieg, 1981) and formation of gas from nitrate was not detected using Durham tubes under anaerobic conditions.

The sensitivity to antimicrobial agents was tested with discs impregnated with the particular antimicrobial agents placed on pre-inoculated plates. Inhibitory zones around the discs were recorded after incubation for 3 days at $37^{\circ} \mathrm{C}$. Strain $\mathrm{BH} 2^{\mathrm{T}}$ was sensitive to ampicillin $\left(50 \mu \mathrm{g} \mathrm{disc}{ }^{-1}\right)$, bacitracin $\left(25 \mu \mathrm{g} \mathrm{disc}^{-1}\right)$, chloramphenicol $\left(25 \mu \mathrm{g} \mathrm{disc}^{-1}\right)$ and novobiocin $\left(25 \mu \mathrm{g} \mathrm{disc}{ }^{-1}\right)$, whereas it was resistant to kanamycin $\left(50 \mu \mathrm{g} \mathrm{disc}^{-1}\right)$, streptomycin $\left(100 \mu \mathrm{g} \mathrm{disc}^{-1}\right)$, tetracycline $\left(50 \mu \mathrm{g} \mathrm{disc}^{-1}\right)$ and anisomycin $\left(50 \mu \mathrm{g} \mathrm{disc}{ }^{-1}\right)$.

HPLC analysis of isoprenoid quinones and GC/MS analysis of fatty acid methyl esters were performed according to the modified procedures of Tamaoka (1986) and Komagata \& Suzuki (1987). The predominant isoprenoid quinone of strain $\mathrm{BH} 2^{\mathrm{T}}$ was menaquinone-7 (MK-7). The cellular fatty acid profile of strain $\mathrm{BH} 2^{\mathrm{T}}$ was characterized by saturated branched fatty acids such as ai- $\mathrm{C}_{15: 0}, \mathrm{i}-\mathrm{C}_{16: 0}$, ai- $\mathrm{C}_{17: 0}$ and $\mathrm{i}-\mathrm{C}_{15: 0}$.

Preparation of peptidoglycan and determination of its structure were performed according to the modified procedures of Schleifer \& Kandler (1972), Schleifer (1985) and Schlesner et al. (2001). Purified peptidoglycan was hydrolysed in $4 \mathrm{M} \mathrm{HCl}$ at $100^{\circ} \mathrm{C}$ for $16 \mathrm{~h}$ (total hydrolysate) or $45 \mathrm{~min}$ (partial hydrolysate). Diamino acids were identified from the total hydrolysate by using one-dimensional TLC in methanol/pyridine/4 M HCl/water $(80: 10: 4: 26$, by vol.) solvent system. Amino acids and peptides were identified from the partial hydrolysate by using two-dimensional TLC. The first direction was developed in isopropyl alcohol/acetic acid/water $(75: 10: 15$, by vol.) and the second in $\alpha$-dipicolin $/ 25 \%$ ammonium hydrate/water $(70: 2: 28$, by vol). The resulting fingerprints were compared with those from known peptidoglycan structures. Strain $\mathrm{BH}_{2}{ }^{\mathrm{T}}$ possessed $\mathrm{A} 1 \gamma$, meso-diaminopimelic ( $m$ Dpm)-type murein.

Total DNA was extracted by using the method of Saito \& Miura (1963). The 16S rRNA genes were amplified by PCR with the following forward and reverse primers: $5^{\prime}$-AGAGTTTGATCCTGGCTCAG-3' (positions 8-27 according to Escherichia coli numbering) and 5'-GGCTACCTTGTTACGACTT-3' (positions 1510-1492). The amplified DNA was cloned using a TA Cloning kit (Invitrogen) and sequenced using an ABI PRISM BigDye Terminator v3.1 cycle sequencing kit (Applied Biosystems) with the following primers: 5'-GGAAACAGCTATGACCATG-3' (vector side), 5' -GACTACCAGGGTATCTAATC-3' (positions 805-786), 5' AGGGTTGCGCTCGTTG-3' (positions 1115-1100) and 5'-GTAAAACGACGGCCAGT-3' (vector side), using an ABI PRISM 310 Genetic Analyzer (Applied Biosystems). There was little ( 2 or 3 bases) heterogeneity among the sequences (1492 bp) of several clones. The sequence of strain $\mathrm{BH} 2^{\mathrm{T}}$ was shown to be most closely related to three species of the genus Alkalibacillus (Alkalibacillus haloalkaliphilus, Alkalibacillus filiformis and Alkalibacillus salilacus; 94.1-93.6\% sequence similarity), Thalassobacillus devorans (94.0\%), Filobacillus milosensis (94.0\%) and Tenuibacillus multivorans $(92.9 \%)$ by FASTA analysis. The sequences of related strains retrieved from the DNA Database of Japan (DDBJ) (Miyazaki et al., 2003; Pearson \& Lipman, 1988; Lipman \& Pearson, 1985) were aligned using the CLUSTAL W multiple sequence alignment program (Thompson et al., 1994). A phylogenetic tree was reconstructed by using the neighbour-joining method (Saitou \& Nei, 1987) and evaluated by bootstrap sampling (Felsenstein, 1985). Fig. 1 shows that strain $\mathrm{BH} 2^{\mathrm{T}}$ is a member of the family Bacillaceae and is most closely related to the three species of the genus Alkalibacillus, F. milosensis and Tenuibacillus multivorans. The $\mathrm{G}+\mathrm{C}$ content of the total DNA of strain $\mathrm{BH}^{\mathrm{T}}$, determined using the HPLC method of Tamaoka \& Komagata (1984), was $35.1 \pm 0.4 \mathrm{~mol} \%( \pm \mathrm{SD} ; n=5)$. 


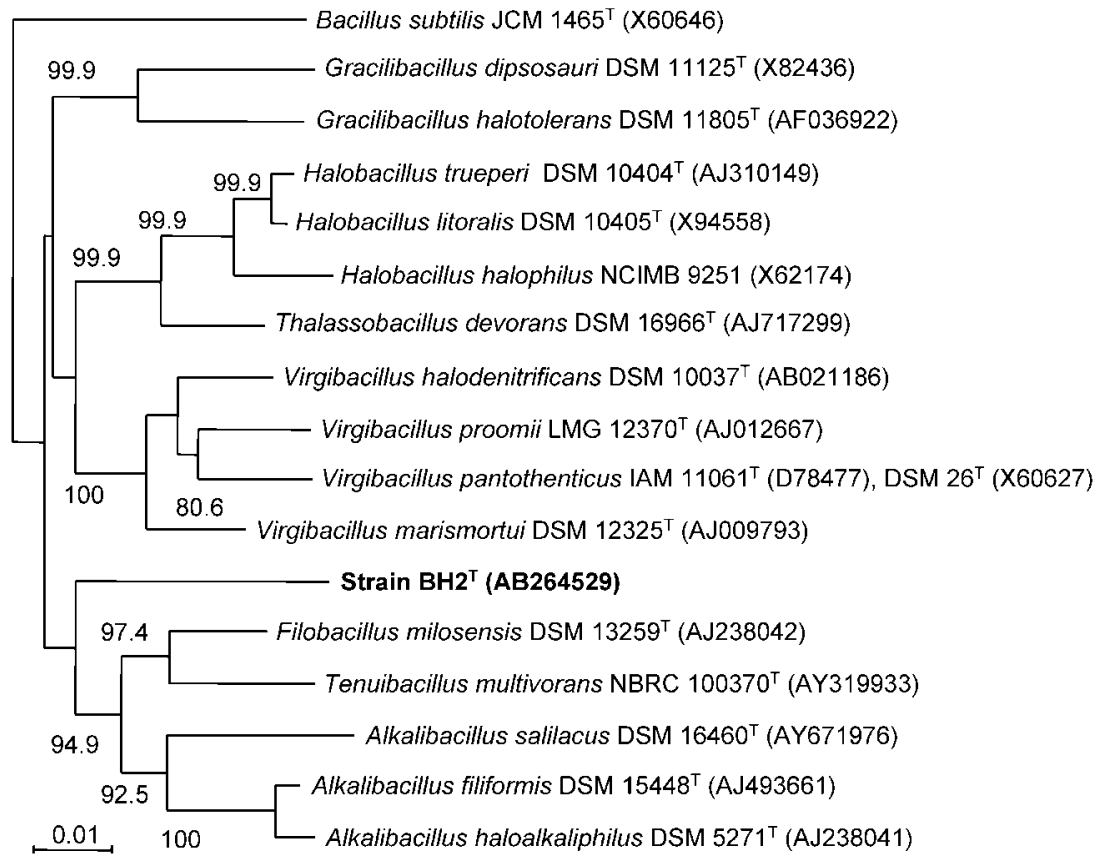

Fig. 1. Neighbour-joining tree based on 16S rRNA gene sequences showing the phylogenetic relationships between strain $\mathrm{BH} 2^{\top}$ and related strains. The sequence of Virgibacillus pantothenticus used was basically that with GenBank accession no. D78477, 16 nucleotides of which were supplemented by the corresponding bases of the sequence with GenBank accession no. X60627. Bootstrap percentages based on 1000 replicates greater than $80 \%$ are shown. Bacillus subtilis JCM $1465^{\top}$ (X60646) was used as an outgroup. Bar, 0.01 changes per nucleotide position. An extended neighbour-joining tree is available as Supplementary Fig. S2 in IJSEM Online.

In terms of phenotypic characteristics, there were differences between strain $\mathrm{BH} 2^{\mathrm{T}}$ and the three most-related species of the genus Alkalibacillus (Fritze, 1996; Jeon et al., 2005; Romano et al., 2005), F. milosensis (Schlesner et al., 2001) and Tenuibacillus multivorans (Ren \& Zhou, 2005), as summarized in Table 1. Strain $\mathrm{BH} 2^{\mathrm{T}}$ grew at $\mathrm{pH}$ 5.5-10.0 with optimal growth at $\mathrm{pH} 8.5-9.0$, whereas $F$. milosensis and Tenuibacillus multivorans were neutrophilic with no growth above $\mathrm{pH}$ 9.0. The Alkalibacillus species were alkaliphilic with no growth below $\mathrm{pH}$ 6.5. The murein type of strain $\mathrm{BH} 2^{\mathrm{T}}$ was $m$-Dpm, as for the related genera Alkalibacillus and Tenuibacillus. F. milosensis was shown to possess $\mathrm{A} 4 \beta$, L-Orn-D-Glu-type murein. The major fatty acid of strain $\mathrm{BH}_{2}^{\mathrm{T}}$ was ai- $\mathrm{C}_{15: 0}\left(\mathrm{i}-\mathrm{C}_{16: 0}\right.$ was the second most abundant), whereas those of the three Alkalibacillus species and Tenuibacillus multivorans were $\mathrm{i}-\mathrm{C}_{15: 0}$ (ai- $\mathrm{C}_{15: 0}$ or ai- $\left.\mathrm{C}_{17: 0}\right)$ and those of $F$. milosensis were ai- $\mathrm{C}_{15: 0}\left(\mathrm{i}-\mathrm{C}_{15: 0}\right)$. Other differences between strain $\mathrm{BH}^{\mathrm{T}}$ and $F$. milosensis occurred in Gram stain, oxidase reaction, hydrolysis of DNA and hippurate and sensitivity to streptomycin, and other differences between strain $\mathrm{BH} 2^{\mathrm{T}}$ and Tenuibacillus multivorans were in hydrolysis of casein, gelatin and aesculin. An alignment of 16S rRNA gene sequences of members of the genera discussed above as well as Gracilibacillus, Halobacillus, Virgibacillus, etc., and some halophilic strains of the genus Bacillus and a phylogenetic tree reconstructed from the alignment are available as Supplementary Figs S1 and S2, respectively, in IJSEM Online. In addition, a table showing signature bases of the genera Alkalibacillus, Filobacillus and Tenuibacillus and strain $\mathrm{BH}^{\mathrm{T}}$ is available as Supplementary Table S1 in IJSEM Online. According to the phylogenetic and phenotypic characteristics, strain $\mathrm{BH} 2^{\mathrm{T}}$ represents a novel species of a new genus, for which the name Halalkalibacillus halophilus gen. nov., sp. nov. is proposed.

\section{Description of Halalkalibacillus gen. nov.}

Halalkalibacillus (Hal.al.ka'li.ba.cil'lus. Gr. n. hals salt; Arabic n. al qaliy soda ash; L. n. bacillus rod; N.L. masc. n. Halalkalibacillus briny and alkaline media loving rods).

Cells are motile with a single polar flagellum, rod-shaped, $0.3-0.5 \times 2.0-3.0 \mu \mathrm{m}$. Spores are spherical, located terminally, with swollen sporangia. Gram-positive. $\mathrm{KOH}$ test and L-alanine aminopeptidase are negative. Cell walls contain A1 $\gamma, m$-Dpm-type murein. No growth occurs in media without $\mathrm{NaCl}$. Alkaliphilic, mesophilic, aerobic and halophilic. Catalase- and oxidase-positive. Reduction of nitrate and gas formation are not observed. The $\mathrm{G}+\mathrm{C}$ content of the total DNA is $35.1 \pm 0.4 \mathrm{~mol} \%$ ( $\pm \mathrm{SD} ; n=5)$. The predominant isoprenoid quinone is $\mathrm{MK}-7$. Major cellular fatty acids are ai- $\mathrm{C}_{15: 0}, \mathrm{i}-\mathrm{C}_{16: 0}$, ai- $\mathrm{C}_{17: 0}$ and $\mathrm{i}-\mathrm{C}_{15: 0}$. The type species is Halalkalibacillus halophilus.

\section{Description of Halalkalibacillus halophilus sp. nov.}

Halalkalibacillus halophilus (ha.lo.phi'lus. Gr. n. hals salt; Gr. adj. philos loving; N.L. masc. adj. halophilus salt loving).

Exhibits the following characteristics in addition to those given in the genus description. Colonies formed on agar are cream-like and opaque. Growth occurs in 5.0-25\% (w/v) $\mathrm{NaCl}$, with optimum growth at $10-15 \%(w / v) \mathrm{NaCl}$. Growth occurs at $\mathrm{pH}$ 5.5-10.0, with optimum growth at $\mathrm{pH}$ 8.5-9.0. Temperature range for growth is $20-40{ }^{\circ} \mathrm{C}$, with optimum 
Table 1. Differential characteristics of strain $\mathrm{BH}^{\top}$ and related taxa

Strains: 1 , strain $\mathrm{BH} 2^{\mathrm{T}} ; 2$, A. haloalkaliphilus JCM $12303^{\mathrm{T}} ; 3$, A. filiformis DSM $15448^{\mathrm{T}} ; 4$, A. salilacus DSM $16460^{\mathrm{T}}$; 5, F. milosensis DSM $13259^{\mathrm{T}} ; 6$, Tenuibacillus multivorans NBRC $100370^{\mathrm{T}}$. Data from Fritze (1996), Jeon et al. (2005), Ren \& Zhou (2005), Romano et al. (2005), Schlesner et al. (2001) and this study (strain $\mathrm{BH} 2^{\mathrm{T}}$ and A. haloalkaliphilus JCM $12303^{\mathrm{T}}$ ). +, Positive; -, negative; W, weak; ND, no data.

\begin{tabular}{|c|c|c|c|c|c|c|}
\hline Characteristic & 1 & 2 & 3 & 4 & 5 & 6 \\
\hline Cell morphology & Short rods & Long rods & Long rods & Rods & Long rods & Rods \\
\hline Colonial pigmentation & Cream & $\begin{array}{l}\text { Cream- } \\
\text { white }\end{array}$ & $\begin{array}{l}\text { White } \\
\text { transparent }\end{array}$ & Cream & $\begin{array}{l}\text { White } \\
\text { transparent }\end{array}$ & Translucent \\
\hline Motility & + & + & - & + & + & + \\
\hline Gram stain & + & - & + & + & - & + \\
\hline $\mathrm{KOH}$ test & - & - & + & - & - & - \\
\hline $\begin{array}{l}\text { Salinity range for growth (optimum) } \\
(\%)\end{array}$ & $\begin{array}{c}5-25 \\
(10-15)\end{array}$ & $\begin{array}{c}0-20 \\
(5-10)\end{array}$ & $0-18(10)$ & $\begin{array}{c}5-20 \\
(10-12)\end{array}$ & $2-23(8-14)$ & $1-20(5)$ \\
\hline $\mathrm{pH}$ range for growth (optimum) & $\begin{array}{l}5.5-10.0 \\
(8.5-9.0)\end{array}$ & $\begin{array}{l}7.5-10.0 \\
(9.0-9.5)\end{array}$ & $\begin{array}{l}7.0-10.0 \\
(9.0)\end{array}$ & $\begin{array}{c}7.0-9.0 \\
(8.0)\end{array}$ & $\begin{array}{c}6.5-8.9 \\
(7.3-7.8)\end{array}$ & $\begin{array}{c}6.5-9.0 \\
(7.0-8.0)\end{array}$ \\
\hline $\begin{array}{l}\text { Temperature range for growth } \\
\text { (optimum) }\left({ }^{\circ} \mathrm{C}\right)\end{array}$ & $\begin{array}{c}20-40 \\
(30-37)\end{array}$ & $\begin{array}{c}20-40 \\
(30-37)\end{array}$ & $\begin{array}{c}15-45 \\
(30)\end{array}$ & $\begin{array}{c}15-40 \\
(30)\end{array}$ & $-42(33-38)$ & $\begin{array}{c}21-42 \\
(36-41)\end{array}$ \\
\hline Acid production from D-fructose & - & ND & - & $\mathrm{W}$ & - & - \\
\hline Catalase & + & + & $\mathrm{W}$ & + & + & + \\
\hline Oxidase & + & + & - & - & - & + \\
\hline \multicolumn{7}{|l|}{ Hydrolysis of: } \\
\hline Starch & - & $\mathrm{W}$ & - & - & - & - \\
\hline Casein & - & + & - & - & - & + \\
\hline Gelatin & - & + & + & - & - & + \\
\hline DNA & - & ND & - & ND & + & ND \\
\hline Hippurate & - & + & - & + & + & ND \\
\hline Aesculin & - & $\mathrm{ND}$ & $\mathrm{ND}$ & + & - & + \\
\hline Reduction of nitrate & - & - & - & + & - & - \\
\hline \multicolumn{7}{|l|}{ Sensitive to: } \\
\hline Streptomycin & - & - & - & $\mathrm{ND}$ & + & ND \\
\hline Tetracycline & - & + & - & ND & + & ND \\
\hline DNA G $+C$ content $(\mathrm{mol} \%)$ & $\begin{array}{l}35.1 \pm 0.4 \\
\quad(n=5)\end{array}$ & 38.0 & 39.5 & 41.0 & 35 & $36.5-37$ \\
\hline Murein type & $m$-Dpm & $m$-Dpm & $m$-Dpm & $m-\mathrm{Dpm}$ & L-Orn & $m$-Dpm \\
\hline Isoprenoid quinone & MK-7 & MK-7 & $\begin{array}{c}\text { MK-7, } \\
\text { DemethylMK-6 }\end{array}$ & MK-7 & ND & ND \\
\hline Major fatty acids & $\begin{array}{l}\text { ai- } \mathrm{C}_{15: 0} \\
\mathrm{i}-\mathrm{C}_{16: 0}\end{array}$ & $\begin{array}{l}\mathrm{i}-\mathrm{C}_{15: 0} \\
\text { ai- } \mathrm{C}_{15: 0}\end{array}$ & $\begin{array}{l}\mathrm{i}-\mathrm{C}_{15: 0} \\
\text { ai- } \mathrm{C}_{17: 0}\end{array}$ & $\begin{array}{l}\mathrm{i}-\mathrm{C}_{15: 0} \\
\text { ai- } \mathrm{C}_{15: 0}\end{array}$ & $\begin{array}{l}\text { ai- } \mathrm{C}_{15: 0} \\
\mathrm{i}-\mathrm{C}_{15: 0}\end{array}$ & $\begin{array}{l}\mathrm{i}-\mathrm{C}_{15: 0} \\
\text { ai- } \mathrm{C}_{15: 0}\end{array}$ \\
\hline
\end{tabular}

growth at $30-37^{\circ} \mathrm{C}$. Anaerobic growth is not observed. Acid is not produced from D-galactose, maltose, sucrose, Dtrehalose, D-mannitol, D-fructose, D-glucose or D-xylose. Starch, gelatin, casein, DNA, hippurate, aesculin, pullulan and Tween 80 are not hydrolysed. Sensitive to ampicillin, bacitracin, novobiocin and chloramphenicol; resistant to tetracycline, streptomycin, kanamycin and anisomycin.

The type strain is strain $\mathrm{BH} 2^{\mathrm{T}}\left(=\mathrm{JCM} 14192^{\mathrm{T}}=\mathrm{DSM}\right.$ $18494^{\mathrm{T}}$ ), which was isolated from non-saline surface soil from a garden in Niiza City, Saitama Prefecture, Japan.

\section{Acknowledgements}

Part of this study was supported by a grant for the 21st Century Center of Excellence Programs organized by the Ministry of Education,
Culture, Sports, Science and Technology, Japan, since 2003, and Research Fellowships of the Japan Society for the Promotion of Science for Young Scientists to A. E.

\section{References}

Dussault, H. P. (1955). An improved technique for staining redhalophilic bacteria. J Bacteriol 70, 484-485.

Echigo, A., Hino, M., Fukushima, T., Mizuki, T., Kamekura, M. \& Usami, R. (2005). Endospores of halophilic bacteria of the family Bacillaceae isolated from non-saline Japanese soil may be transported by Kosa event (Asian dust storm). Saline Systems 1, 8.

Felsenstein, J. (1985). Confidence limits on phylogenies: an approach using the bootstrap. Evolution 39, 783-791.

Fritze, D. (1996). Bacillus haloalkaliphilus sp. nov. Int J Syst Bacteriol 46, 98-101. 
Gregersen, T. (1978). Rapid method for distinction of gramnegative from gram-positive bacteria. Eur J Appl Microbiol Biotechnol 5, 123-127.

Jeon, C. O., Lim, J. M., Lee, J. M., Xu, L. H., Jiang, C. L. \& Kim, C. J. (2005). Reclassification of Bacillus haloalkaliphilus Fritze 1996 as Alkalibacillus haloalkaliphilus gen. nov., comb. nov. and the description of Alkalibacillus salilacus sp. nov., a novel halophilic bacterium isolated from a salt lake in China. Int J Syst Evol Microbiol 55, 1891-1896.

Kodaka, H., Armfield, A. Y., Lombard, G. L. \& Dowell, V. R., Jr (1982). Practical procedure for demonstrating bacterial flagella. $J$ Clin Microbiol 16, 948-952.

Komagata, K. \& Suzuki, K. (1987). Lipid and cell wall analysis in bacterial systematics. Methods Microbiol 19, 161-207.

Kushner, D. J. \& Kamekura, M. (1988). Physiology of halophilic eubacteria. In Halophilic Bacteria, vol. I, pp. 109-140. Boca Raton, FL: CRC Press.

Lenore, S. C., Arnold, E. G. \& Andrew, D. E. (1998). Standard Methods for the Examination of Water and Wastewater, 20th edn. Washington, DC: American Public Health Association, the American Water Works Association and the Water Environment Federation.

Lipman, D. J. \& Pearson, W. R. (1985). Rapid and sensitive protein similarity searches. Science 227, 1435-1441.

Miyazaki, S., Sugawara, H., Gojobori, T. \& Tateno, Y. (2003). DNA Data Bank of Japan (DDBJ) in XML. Nucleic Acids Res 31, $13-16$.

Murray, P. R., Baron, E. J., Pfaller, M. A., TeNover, F. C. \& Yolken, R. H. (1999). Manual of Clinical Microbiology, 7th edn. Washington DC: American Society for Microbiology.

Oren, A. (2002). Halophilic Microorganisms and their Environments. Dordrecht: Kluwer Academic.

Oren, A., Ventosa, A. \& Grant, W. D. (1997). Proposed minimal standards for description of new taxa in the order Halobacteriales. Int J Syst Bacteriol 47, 233-238.

Pearson, W. R. \& Lipman, D. J. (1988). Improved tools for biological sequence comparison. Proc Natl Acad Sci U S A 85, 2444-2448.
Ren, P. G. \& Zhou, P. J. (2005). Tenuibacillus multivorans gen. nov., sp. nov., a moderately halophilic bacterium isolated from saline soil in Xin-Jiang, China. Int J Syst Evol Microbiol 55, 95-99.

Romano, I., Lama, L., Nicolaus, B., Gambacorta, A. \& Giordano, A. (2005). Alkalibacillus filiformis sp. nov., isolated from a mineral pool in Campania, Italy. Int J Syst Evol Microbiol 55, 2395-2399.

Saito, H. \& Miura, K. (1963). Preparation of transforming deoxyribonucleic acid by phenol treatment. Biochim Biophys Acta 72, 619-629.

Saitou, N. \& Nei, M. (1987). The neighbor-joining method: a new method for reconstructing phylogenetic trees. Mol Biol Evol 4, 406-425.

Schleifer, K. H. (1985). Analysis of the chemical composition and primary structure of murein. Methods Microbiol 18, 123-156.

Schleifer, K. H. \& Kandler, O. (1972). Peptidoglycan types of bacterial cell walls and their taxonomic implications. Bacteriol Rev 36, 407-477.

Schlesner, H., Lawson, P. A., Collins, M. D., Weiss, N., Wehmeyer, U., Völker, H. \& Thomm, M. (2001). Filobacillus milensis gen. nov., sp. nov., a new halophilic spore-forming bacterium with Orn-D-Glutype peptidoglycan. Int J Syst Evol Microbiol 51, 425-431.

Smibert, R. M. \& Krieg, N. R. (1981). General characterization. In Manual of Methods for General Microbiology, pp. 409-443. Edited by P. Gerhardt, R. G. E. Murray, R. N. Costilow, E. W. Nester, W. A. Wood, N. R. Krieg \& G. B. Phillips. Washington, DC: American Society for Microbiology.

Smibert, R. M. \& Krieg, N. R. (1994). Phenotypic characterization. In Methods for General and Molecular Bacteriology, pp. 607-654. Edited by P. Gerhardt. Washington, DC: American Society for Microbiology.

Tamaoka, J. (1986). Analysis of bacterial menaquinone mixtures by reverse-phase high-performance liquid chromatography. Methods Enzymol 123, 251-256.

Tamaoka, J. \& Komagata, K. (1984). Determination of DNA base composition by reversed-phase high-performance liquid chromatography. FEMS Microbiol Lett 25, 125-340.

Thompson, J. D., Higgins, D. G. \& Gibson, T. J. (1994). CLUSTAL W: improving the sensitivity of progressive multiple sequence alignment through sequence weighting, position-specific gap penalties and weight matrix choice. Nucleic Acids Res 22, 4673-4680. 